\title{
Public Libraries in Africa
}

There is great need for public libraries in Africa, especially in those regions where mass education programmes are teaching many people how to read. In view of this need UNESCO is organizing a seminar on the development of public libraries in Africa, which will be held at the University College, Ibadan, Nigeria, 27 July-21 August 1953. The seminar will be limited to 30 participants, plus observers (to be selected by the member States taking part); UNESCO may also invite, in an individual capacity, certain experts whose contribution would be particularly valuable. The Seminar will be directed by Mlle Yvonne Oddoy, Librarian of the Musée de l'Homme, Paris, and work will be carried out in plenary sessions and in meetings of three working groups. The subjects for discussion include: Organization of public library services on a regional or national scale; selection and use of publications and audio-visual material; professional training. Each participant and observer is expected to bring to the seminar a paper on the condition and chief problems of public library services in his own country or territory.

\section{African Music}

The International Folk Music Council held its fifth Annual Conference in London in July 1952. A resolution of the Conference laid stress on the importance of the cultivation and preservation of African indigenous music and dances, and urged that steps should be taken to promote concerts of folk music in schools and youth organizations; to hold Regional African musical festivals; to organize musical surveys and to provide grants and bursaries for carrying out such surveys. In particular the Council recommended that financial assistance should be given by governments and other interested bodies to the African Music Society, to enable it to engage a professional staff of musicians and linguists, and that professors from English colleges of music should make research tours in Africa in order to study African musical idiom.

\section{Africa: Quarterly Bibliography}

IN view of the ever increasing output of literature in African languages, the vernacular section of the Bibliography published in this journal will in future be confined to those works which are most likely to be of interest to our readers. We shall continue to list the first few works in a language in which little or nothing has previously been published. First editions of parts of the Bible, vernacular grammars, and any other works of special linguistic value will also be listed, as well as some original works by Africans, especially those of ethnological interest.

Those of our readers who require a more complete list of school textbooks and literacy material should consult the bibliography appearing each quarter in Books for Africa, the Bulletin of the International Committee on Christian Literature for Africa, Edinburgh House, 2 Eaton Gate, S.W. 1. The various Literature Bureaux in Africa can, of course, also be consulted with regard to the literature of their areas. 